\title{
STRATEGI PEMASARAN TERHADAP PENINGKATAN LOYALITAS KONSUMEN JAMUR TIRAM DI UD. IRZAN (STUDI KASUS DI DESA KALIBAGOR KECAMATAN SITUBONDO KABUPATEN SITUBONDO)
}

\author{
Ckhoirul Umam ${ }^{1 *}$ ), Sutrisno2) \\ Program Studi Agribisnis, Fakultas Pertanian, Universitas Abdurachman Saleh Situbondo \\ Email Korespondensi : Ckhoirulumam83@gmail.com
}

\begin{abstract}
Abstrak
Pemasaran adalah salah satu kegiatan dalam perekonomian yang membantu dalam menciptakan nilai ekonomi. Nilai ekonomi itu sendiri menentukan harga barang dan jasa. Pemasaran produk pertanian sangat berbeda dengan berbagai produk lain sebab mudah rusak dan tidak tahan lama, karenanya para pelaku dibidang ini harus mempertimbangkan berbagai hal di dalam pemasaran yang berimbas pada kepuasan konsumen, dimana hal tersebut sangat menentukan loyalitas konsumen terhadap produk pertanian. Jamur tiram (Pleurotus Ostreatus) merupakan salah satu jamur kayu yang banyak diminati oleh masyarakat. Tanaman ini merupakan salahsatu tanaman yang dibudidayakan secrara intensif oleh sebagian petani di Desa Kalibagor Kecamatan Situbondo Kabupaten Situbondo sekitar 3 tahun terakhir. Strategi pemasaran merupakan faktor utama yang mempengaruhi timbulnya loyalitas konsumen, karenanya variabelvariabel dalam strategi pemasaran berupa Produk (Product), Harga (Place), Lokasi (Place), Promosi (Promotion), ketersediaan produk dan harga merupakan aspek yang dikaji guna melihat pengaruhnya terhadap Loyalitas konsumen akan produk Jamur Tiram di Desa Kalibagor. Hasil penelitian menunjukkan bahwa Variabel-variabel dalam strategi pemasaran yang berupa produk (product), harga (place), tempat (place), promosi (promotion) tidak berpengaruh terhadap loyalitas konsumen akan produk jamur tiram UD. IRZAN di Desa Kalibagor, Kecamatan Situbondo, Kabupaten Situbondo hanya secara simultan atau bersama-sama dengan besaran pengaruh yang ditimbulkan adalah 52,3\% sesdangkan sisanya yakni sebesar $47,7 \%$ dipengaruhi oleh variabel lain diluar penelitian ini.
\end{abstract}

Kata Kunci: Pemasaran, Jamur Tiram, Petani Desa Kalibagor, Strategi Pemasaran, Loyalitas Konsumen

\begin{abstract}
Marketing is one of the activities in the economy that helps in creating economic value. The economic value itself determines the prices of goods and services. Marketing of agricultural products is very different from other products because it is easily damaged and not durable, so the actors in this field must consider various things in marketing that impact on customer satisfaction, which greatly determines consumer loyalty to agricultural products. Oyster mushroom (Pleurotus Ostreatus) is one of the wood fungus that is much in demand by the public. This plant is one of the most intensively cultivated plants by some farmers in Kalibagor Village, Situbondo District, Situbondo Regency for the last 3 years. Marketing strategy is the main factor that influences the emergence of consumer loyalty, therefore the variables in the marketing strategy in the form of Product (Product), Price (Place), Location (Place), Promotion (Promotion), product availability and price are aspects that are studied in order to see the effect on consumer loyalty for Oyster Mushroom products in Kalibagor Village. The results showed that the variables in the marketing strategy in the form of product, price, place, promotion did not affect consumer loyalty to UD oyster mushroom
\end{abstract}


products. IRZAN in Kalibagor Village, Situbondo Subdistrict, Situbondo District only simultaneously or together with the magnitude of the effect it caused was 52.3\% while the remaining $47.7 \%$ was influenced by other variables outside this study.

Keywords: Marketing, Oyster Mushrooms, Kalibagor Village Farmers, Marketing Strategies, Consumer Loyalty.

\section{PENDAHULUAN}

Pemasaran adalah salah satu kegiatan dalam perekonomian yang membantu dalam menciptakan nilai ekonomi. Nilai ekonomi itu sendiri menentukan harga barang dan jasa. Faktor penting dalammenciptakan nilai tersebut adalah produksi, pemasaran dan konsumsi. Pemasaran menjadi penghubung antara kegiatan produksi dan konsumsi. Banyak ahli yang telah memberikan defines atas pemasaran ini. Dalam kegiatan pemasaran ini, aktivitas pertukara nmerupakan hal sentral. Pertukaran merupakan kegiatan pemasaran dimana seseorang berusaha menawarkan sejumlah barang atau jasa dengan sejumlah nilai ke berbagai macam kelompok social untuk memenuhi kebutuhannya.

Kotler (1997) menyatakan bahwa "Strategi Pemasaran adalah suatu proses social dan manajerial yang didalamnya induvidu dan kelompok mendapatkan apa yang mereka butuhkan dan inginkan dengan menciptakan, menawarkan, dan mempertukarkan produk yang bernilai kepada pihak lain". Dengan demikian pemasaran bias juga diartikan suatu usaha untuk memuaskan kebutuhan pembeli dan penjual (Swasta, 1996).

Berdasarkan penjabaran strategi pemasaran diatas sangat penting untuk mengetahui variabel-variabel penentu dalam strategi pemasaran terhadap loyalitas konsumen yang perlu dipahami oleh setiap pelaku usaha. Variabel yang terdapat didalamnya adalah produk, harga, promosi dan tempat. Maka peneliti menetapkan variabel-variabel dalam strategi pemasaran terdiri dari empat aspek yang perlu diperhatikan, yaitu produk, harga, promosi dan tempat.

Produk menurut Kotler dan Amstrong adalah segala sesuatu yang ditawarkan kepasar untuk mendapatkan perhatian, dibeli, dipergunakan dan yang dapat memuaskan keinginan dan kebutuhan konsumen. Harga merupakan salah satu penentu keberhasilan suatu perusahaan karena harga menentukan seberapa besar keuntungan yang akan diperoleh perusahaan dari penjualan produknya baik berupa barang atau jasa. Promosi adalah upaya untuk memberitahukan atau menawarkan produk atau jasa dengan tujuan menarik calon konsumen untuk membeli atau mengkonsumsinya. Dengan adanya promosi, produsen atau distributor mengharapkan kenaikannya angka penjualan. Menurut Kotler dan Amstrong (2008) lokasi atau tempat merupakan kegiatan perusahaan yang membuat produk tersedia bagi pelanggan sasaran. Lokasi merupakan tempat melayani konsumen, dapat pula diartika sebagai tempat untuk memajangkan batangbatang dagangannya (Kasmir, 2009).

Tujuan penelitian untuk mengetahui pengaruh variabel-variabel berupa Produk (Product), Harga (Price), Tempat (Place), Promosi (Promotion), terhadap loyalitas konsumen jamur tiram yang dihasilkan oleh para petani di Desa Kalibagor.

\section{METODE PENELITIAN}

\section{Lokasi dan Waktu Penelitian}

Penelitian ini dilaksanakan di UD. IRZAN Desa Kalibagor Rt:03/Rw:04, Kecamatan Situbondo, Kabupaten Situbondo. Pemilihan lokasi dilakukan secara Purposive dengan pertimbangan bahwa daerah tersebut merupakan sentra produksi jamur tiram di Kabupaten Situbondo. Pengumpulan data dilakukan selama bulan Januari - Mei 2018. 


\section{Populasi}

Populasi merupakan kumpulan individu atau objek penelitian yang memiliki kualitas serta ciri-ciri yang telah ditetapkan. Setelah melakukan observasi, maka ditetapkan populasi pada penelitian ini adalah sebanyak 127 konsumen, yang seluruhnya didapat selama melakukan obervasi di UD. Irzan selama satu minggu dengan beragam jenis konsumen, yakni konsumen tetap dan konsumen baru.

\section{Sampel}

Penarikan konsumen sampel dari produk jamur tiram menggunakan teknik purposive sampling, yaitu teknik penentuan sampel dengan pertimbangan tertentu (Sugiyono, 2013) dengan teknik penentuan sampel untuk tujuan mengetahui Loyalitas mereka terhadap produk jamur tiram di Desa Kalibagor.

Sampel ditentukan berdasarkan pada perhitungan dari rumus Slovin dengan tingkat kesalahan yang ditoleransi sebesar 10\% (Umar Husein 2003).

$$
\mathrm{n}=\frac{N}{1+N\left(e^{2}\right)}
$$

Keterangan :

$\mathrm{n}=$ Ukuran Sampel

$\mathrm{N}=$ Ukuran Populasi

$\mathrm{e}=$ Persen kelonggaran ketidaktelitian karena kesalahan pengambilan

sampel yang masih dapat ditolerir atau diinginkan, sebanyak $10 \%$.

Berdasarkan rumus tersebut, maka jumlah konsumen sampel yang diambil dalam penelitian ini adalah:

$$
\begin{aligned}
& \mathrm{n}=\frac{127}{1+127\left(10 \%^{2}\right)} \\
& \mathrm{n}=\frac{127}{2,27} \\
& \mathrm{n}=55,94=56 \text { konsumen sampel }
\end{aligned}
$$

Jumlah konsumen sampel yang digunakan dalam penelitian ini sebanyak 56 responden, dengan kriteria konsumen yang dipilih adalah konsumen yang membeli produk tersebut dengan tujuan untuk di konsumsi sendiri atau dijual kembali serta pembelian dilakukan setiap hari dalam kurun waktu pembelian selama tiga tahun terakhir.

\section{Teknik Pengumpulan Data}

Dalam suatu penelitian, metode pengumpulan data merupakan suatu faktor yang penting, karena penghitungan diperoleh dari data yang didapatkan dalam penelitian. Metode yang digunakan dalam pengumpulan data pada penelitian ini adalah pengamatan, wawancara, kuisioner, dan dokumentasi.

\section{Metode Analisis Data}

Sehubungan dengan masalah yang dikemukakan sebelumnya, maka akan dilakukan analisa berdasarkan data yang diperoleh dengan menggunakan peralatan analisis sebagai berikut:

\section{Analisis Regresi Linier Berganda}

Analisis ini digunakan untuk mengetahui seberapa besar pengaruh variabel-variabel bebas yaitu Produk (X1), Harga (X2), Tempat (X3), dan Promosi (X4) terhadap variabel terikat yaitu Loyalitas Konsumen (Y) di Desa Kalibagor Kecamatan Situbondo Kabupaten Situbondo. Menurut Sugiyono, (2010) untuk mengetahui pengaruh variabel bebas terhadap variabel terikat digunakan rumus analisis regresi linier berganda sebagai berikut: 


$$
Y=\alpha+b_{1} x_{1}+b_{2} x_{2}+b_{3} x_{3}+b_{4} x_{4}+e
$$

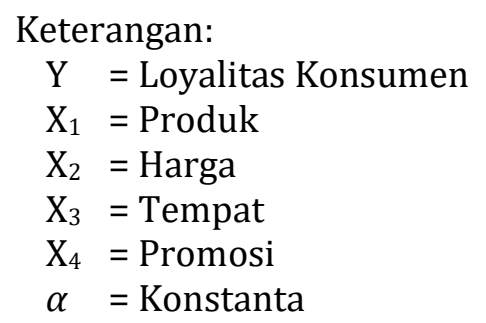

$b 1-b 4=$ Koefisien regresi

$e \quad=$ Toleransi ketidakaktifan/epsilon

\section{Variabel Bebas}

Variabel bebas (independent) adalah variabel yang dapat dimanipulasi oleh peneliti sesuai kebutuhan.Variabel bebas juga disebut sebagai variabel yang mempengaruhi variabel terikat (dependent), baik yang pengaruhnya positif maupun yang pengaruhnya negatif (Ferdinand, 2006). Variabel bebas dalam penelitian ini terdiri dari lima variabel, yakni:

\section{Variabel Terikat}

1. Produk (X1)

2. Harga (X2)

3. Tempat (X3)

4. Promosi (X4)

Variabel bebas (independent) adalah variabel yang dapat dimanipulasi oleh peneliti sesuai kebutuhan.Variabel bebas juga disebut sebagai variabel yang mempengaruhi variabel terikat (dependent), baik yang pengaruhnya positif maupun yang pengaruhnya negatif (Ferdinand, 2006). Variabel bebas dalam penelitian ini terdiri dari lima variabel, yakni:
1. Produk (X1)
2. Harga (X2)
3. Tempat (X3)
4. Promosi (X4)

\section{Pengujian Secara Simultan (Uji F)}

Uji $\mathrm{F}$ digunakan untuk menguji hipotesis nol bahwa koefisien determinasi majemuk dalam populasi, R2 sama dengan nol. Uji signifikansi meliputi pengujian signifikansi persamaan regresi secara keseluruhan serta koefisien regresi parsial spesifik. Uji keseluruhan dapat dilakukan dengan menggunakan statistik F. Kemudian untuk menguji keberartian dari koefisien regresi secara simultan, digunakan pengujian statistik uji $\mathrm{F}$ dengan formulasi sebagai berikut (Gujarati, 2000):

$$
\begin{array}{|l|}
\hline \mathrm{Uji} F=\frac{r^{2} / k}{\left(1-R^{2}\right) /(n-k-1)} \\
\hline \text { Keterangan: } \\
\mathrm{F}=\text { Diperoleh dari tabel distribusi } \\
\mathrm{k}=\text { Jumlah variabel bebas } \\
\mathrm{R}^{2}=\text { Koefisien determinasi ganda } \\
\mathrm{n}=\text { Jumlah sampel }
\end{array}
$$

Dasar pengambilan keputusan (Ghozali, 2005):

a. Dengan membandingkan nilai $F$ hitung dengan $F$ tabel

1) Apabila F hitung $\geq F$ tabel, maka Ho ditolak dan Ha diterima, artinya variabel bebas secara simultan berpengaruh signifikan terhadap variabel terikat. 
2) Apabila $F$ hitung < F tabel, maka Ho di terima dan Ha ditolak, artinya variabel bebas secara simultan tidak berpengaruh signifikan terhadap variabel terikat.

b. Dengan menggunakan angka probabilitas signifikansi

1) Apabila probabilitas signifikansi $>0,05$, maka Ho diterima dan Ha ditolak, artinya variabel bebas secara simultan tidak berpengaruh signifikan terhadap variabel terikat.

2) Apabila probabilitas signifikansi $<0,05$, maka Ho ditolak dan Ha diterima, artinya variabel bebas secara simultan berpengaruh signifikan terhadap variabel terikat.

Penentuan nilai F tabel diperoleh dari:

$$
\begin{aligned}
& \text { dfN1 = k-1 } \\
& \mathrm{dfN} 2=\mathrm{n}-\mathrm{k} \\
& \text { Keterangan: } \\
& \begin{aligned}
\mathrm{df} & =\text { degree of freedom } \\
\mathrm{n} & =\text { jumlah sampel } \\
\mathrm{k} & =\text { jumlah variabel (bebas dan terikat) }
\end{aligned}
\end{aligned}
$$

\section{Pengujian Secara Parsial (Uji t)}

Uji t digunakan untuk menguji signifikansi hubungan antara variabel $X$ dan variabel $Y$, apakah variabel X1, X2, X3, dan X4 benar-benar berpengaruh terhadap variabel Y. Menurut Sugiyono (2004) formulasi perhitungan uji t adalah sebagai berikut:

$$
\mathrm{t}=\frac{r \sqrt{n}-2}{\sqrt{1}-r^{2}}
$$

$$
\begin{aligned}
& \text { Keterangan: } \\
& \mathrm{t}=\text { Nilai hitung } \\
& \mathrm{r}=\text { Koefisien korelasi } \\
& \mathrm{n}=\text { Banyaknya observasi }
\end{aligned}
$$

Dasar pengambilan keputusan (Ghozali, 2005):

a. Dengan membandingkan nilai t hitungnya dengan $t$ tabel, dengan tingkat signifikansi 95

$\%$ atau $\alpha 5 \%$.

1) Apabila t hitung $\geq t$ tabel atau - $t$ hitung $\leq-t$ tabel, maka Ho ditolak dan Ha diterima, artinya variabel bebas secara parsial berpengaruh signifikan terhadap variabel terikat.

2. Apabila $\mathrm{t}$ hitung $<\mathrm{t}$ tabel atau $-\mathrm{t}$ hitung $>-\mathrm{t}$ tabel, maka Ho di terima dan Ha di tolak, artinya variabel bebas secara parsial tidak berpengaruh signifikan terhadap variabel terikat.

b. Dengan menggunakan angka probabilitas signifikansi.

1) Apabila angka probabilitas signifikansi $>0,05$, maka Ho diterima dan Ha ditolak, artinya variabel bebas secara parsial tidak berpengaruh signifikan terhadap variabel terikat.

2) Apabila angka probabilitas signifikansi $<0,05$, maka Ho ditolak dan Ha diterima, artinya variabel bebas secara parsial berpengaruh signifikan terhadap variabel terikat. 
Penentuan nilai t tabel berdasarkan taraf signifikansi sebesar 95\% dan taraf derajat kebebasan $(\mathrm{df})=\mathrm{n}-\mathrm{k}(\alpha / 2)$.

Keterangan :

$\mathrm{df}=$ degree of freedom

$\mathrm{n}=$ jumlah sampel

$\mathrm{k}=$ jumlah variabel (bebas dan terikat)

$\alpha=5 \%$

\section{Koefisien Determinasi}

Koefisien determinan merupakan besaran yang memberikan informasi mengenai proposi variasi dalam variabel terikat oleh variabel bebas (Gujarati, 2006). Uji statistik R2 dapat dicari dengan rumus:

$$
\mathrm{Kd}=\mathrm{r}^{2} \times 100 \%
$$

Keterangan:

$$
\mathrm{Kd}=\text { Koefisien determinan }
$$

$r=$ Koefisien korelasi

Dimana Apabila:

a. $K d=0$, berarti pengaruh variabel $X$ terhadap variabel $Y$, lemah.

b. $\mathrm{Kd}=1$, berarti pengaruh variabel $\mathrm{X}$ terhadap variabel $\mathrm{Y}$, kuat.

Koefisien determinasi $(\mathrm{Kd})$ pada intinya mengukur seberapa jauh kemampuan model dalam menerangkan variasi variabel terikat. Nilai koefisien determinasi berada di antara nol dan satu. Nilai Kd yang kecil berarti kemampuan variabel-variabel bebas dalam menjelaskan variabel terikat amat terbatas. Kesimpulan hipotesis dilakukan berdasarkan t-test dan F-test untuk menguji signifikansi variabel-variabel bebas terhadap variabel terikat.

\section{HASIL DAN PEMBAHASAN}

\section{Analisis Regresi Linier Berganda}

Penghitungan regresi menggunakan program statistik SPSS Statistics 23.0 antara produk (Product), harga (Price), tempat (Place), dan promosi (Promotion) terhadap loyalitas konsumen. Hasil data yang telah diolah dapat dilihat sebagai berikut:

Tabel 1. Hasil Uji F (ANOVA) Variabel-Variabel Yang Berpengaruh Terhadap Loyalitas Konsumen Akan Produk Jamur Tiram di UD. IRZAN.

\begin{tabular}{llrrrrr}
\multicolumn{7}{c}{ ANOVA $^{\mathrm{a}}$} \\
Model & & Sum of Squares & $\mathrm{df}$ & Mean Square & \multicolumn{1}{c}{ F } & \multicolumn{1}{c}{ Sig. } \\
\hline 1 & Regression & 116.205 & 4 & 29.051 & 14.007 & $.000^{\mathrm{b}}$ \\
& Residual & 105.777 & 51 & 2.074 & & \\
& Total & 221.982 & 55 & & & \\
\hline
\end{tabular}

a. Dependent Variable: Loyalitas Konsumen

b. Predictors: (Constant), produk(Product), harga(Price), tempat(Place), promosi(Promotion)

Berdasarkan Tabel 1 di atas pengujian dengan uji $\mathrm{F}$ bertujuan untuk melihat keseluruhan variabel bebas memberikan pengaruh pada variabel terikat. Hasil analisis pada Tabel 1 diperoleh nilai $\mathrm{F}$ hitung sebesar 14,007 lebih besar dari $\mathrm{F}$ tabel sebesar 2,55 (F hitung > F tabel). Hal ini menunjukkan bahwa hipotesis yang menyatakan "Seluruh variabel dalam strategi pemasaran berupa produk (Product), harga (Price), tempat (Place), promosi (Promotion) berpengaruh signifikan terhadap loyalitas konsumen produk jamur tiram di UD. IRZAN Desa Kalibagor, Kecamatan Situbondo, Kabupaten Situbondo" diterima. 
Hasil tersebut menunjukkan bahwa secara berasama-sama seluruh variabel bebas produk (Product), harga (Price), tempat (Place), promosi (Promotion)) berpengaruh terhadap loyalitas konsumen akan produk jamur tiram di UD. IRZAN pada taraf kepercayaan 95\%.

Besarnya parameter variabel-variabel yang berpengaruh terhadap loyalitas konsumen akan produk jamur tiram di UD. IRZAN dapat diketahui melalui nilai determinasi $\left(\mathrm{R}^{2}\right)$. Koefisien determinasi berfungsi untuk mengetahui berapa persen pengaruh yang diberikan seluruh variabel bebas secara simultan taerhadap variabel terikat, dan berikut adalah nilai determinasi yang dapat dilihat melalui Tabel 2 :

Tabel 2. Nilai Determinasi ( $\left.\mathrm{R}^{2}\right)$ Model Summary Model Summary

\begin{tabular}{ccccc}
\hline Model & $\mathrm{R}$ & R Square & Adjusted R Square & Std. Error of the Estimate \\
\hline 1 & $.724^{\mathrm{a}}$ & .523 & .486 & 1.440 \\
\hline
\end{tabular}

a. Predictors: (Constant), produk (Product), harga (Price), tempat (Place), promosi

(Promotion)

b. Dependent Variable: Loyalitas Konsumen

Berdasarkan output pada Tabel 2 menunjukkan nilai R Square sebesar 0,523. Hal ini menunjukkan bahwa persentase loyalitas konsumen terhadap produk jamur tiram di UD. IRZAN dapat dijelaskan secara bersama-sama sebesar 52,3\% oleh variabel produk (Product), harga (Price), tempat (Place), promosi (Promotion), serta sebesar 47,7 \% dijelaskan oleh variabel-variabel lain di luar model regresi dalam penelitian ini, yang memiliki pengaruh cukup besar terhadap loyalitas konsumen akan produk jamur tiram di UD. IRZAN selain keempat variabel dalam strategi pemasaran yang telah diuji.

Nilai pengaruh yang ditumbulkan oleh variabel-variabel dalam strategi pemasaran berupa produk (Product), harga (Price), tempat (Place), promosi (Promotion) terhadap loyalitas konsumen akan produk jamur tiram di UD. IRZAN masih sangat rendah, hal itu dikarenakan UD. IRZAN belum mengoptimalkan keempat variabel tersebut guna memuaskan konsumen dengan harapan berimbas pada meningkatnya loyalitas konsumen. Hasil tersebut sesuai dengan teori menurut (Cholifah, 2010) yang mengungkapkan bahwa, pelanggan mempunyai loyalitas yang tinggi akan senantiasa menggunakan produk atau jasa yang disediakan perusahaan, dan tidak akan terpengaruh jasa yang ditawarkan pihak lain, hal tersebut ditimbulkan oleh strategi pemasaran yang diterapkan oleh perusahaan tersebut. Sehingga konsumen akan loyal terhadap suatu produk dari perusahaan tertentu apabila strategi pemsaran yang digunakan peruusahaan bersangkutan sudah baik dan begitupula sebaliknya

Untuk mengetahui seberapa besar pengaruh dari masing-masing variabel bebas yang berupa produk (product), harga (price), tempat (place), promosi (promotion) terhadap loyalitas konsumen akan produk jamur tiram di UD. IRZAN dilakukan dengan uji t dengan hasil dari analisis regresi linier berganda dapat dilihat dari tabel 3 berikut: 
Tabel 3. Hasil Analisis Regresi Linier Berganda Terhadap Variabel-Variabel Yang Mempengaruhi Loyalitas Konsumen Akan Produk Jamur Tiram di Desa Kalibagor.

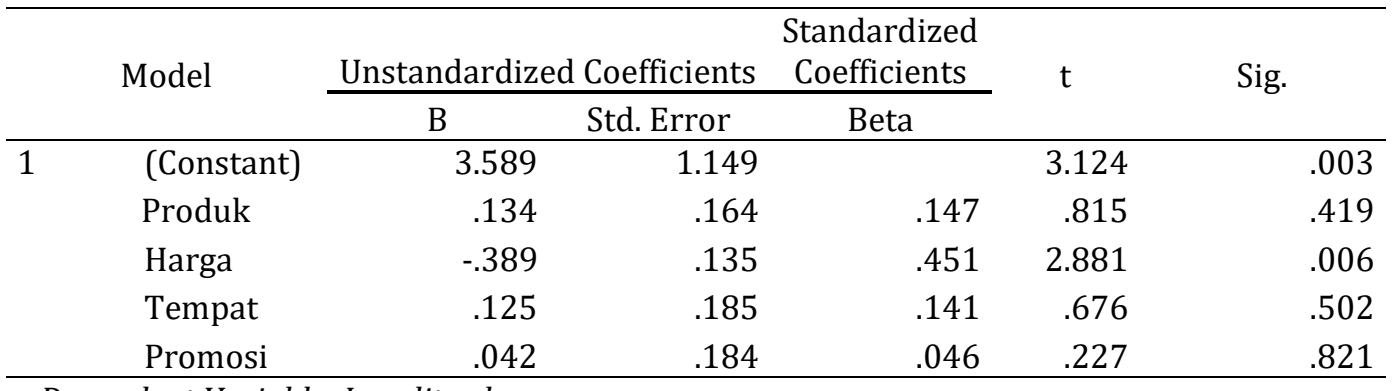

a. Dependent Variable: Loyalitas konsumen

\section{Produk (Product)}

Nilai koefisien regresi kualitas produk adalah sebesar 0,134 yang artinya bahwa setiap peningkatan satu satuan kualitas produk, maka minat beli konsumen akan meningkat sebesar 0,134 poin terhadap pembelian produk jamur tiram di Desa Kalibagor dengan asumsi variabel lainnya tetap. Hal tersebut disebabkan oleh kualitas produk jamur tiram yang segar dan bisa bertahan cukup lama apabila disimpan di lemari pendingin, Sehingga akan mempengaruhi meningkatnya loyalitas konsumen.

Hasil uji regresi linier berganda pada variabel kualitas produk (X1) terhadap koefisien regresi pada Tabel 3 diperoleh nilai t hitung sebesar 0,815 dengan nilai signifikansi sebesar 0,419. Jika signifikan lebih lebih kecil atau sama dengan $(\leq 0,05)$ maka hipotesis diterima. Dari hasil penelitian diperoleh nilai signifikan pada variabel kualitas produk sebesar 0,815 > 0,05 maka disimpulkan hipotesis yang menyatakan "Produk berpengaruh signifikan terhadap loyalitas konsumen akan produk jamur tiram di UD. IRZAN Desa Kalibagor, Kecamatan Situbondo, Kabupaten Situbondo" ditolak. Hasil penelitian ini menunjukkan bahwa variabel produk secara independen tidak berpengaruh signifikan terhadap loyalitas konsumen akan produk jamur tiram di Desa Kalibagor pada tingkat kepercayaan 95\%.

Rendahnya pengaruh variabel produk terhadap loyalitas konsumen dikarenakan pada saat musim kemarau tekstur jamur tiram dapat berubah warna dan tidak segar, ketika saat musim hujan tekstur produk jamur tiram terlalu basah sehingga produk jamur tiram mudah busuk. Menurut Marconi (2010) mengungkapkan bahwa pengurangan standar kualitas dari suatu produk akan mengecewakan konsumen bahkan konsumen yang paling loyal sekalipun. Karena itu pihak perusahaan harus mengontrol kualitas produk.

\section{Harga (Price)}

Nilai koefisien harga adalah sebesar -0,389 yang artinya bahwa setiap peningkatan satu satuan harga sebesar Rp 1, maka akan menurunkan loyalitas konsumen sebesar 0,389 poin terhadap pembelian produk jamur tiram di UD. IRZAN dengan asumsi variabel lainnya tetap.

Hasil uji regresi linier berganda pada variabel harga (X2) terhadap koefisien regresi pada Tabel 3 diperoleh nilai t hitung sebesar 2,881 dengan nilai probabilitas sebesar 0,06. Jika signifikan lebih lebih kecil atau sama dengan $(\leq 0,05)$ maka hipotesis diterima. Dari hasil penelitian diperoleh nilai signifikan pada variabel kualitas produk sebesar 0,06 > 0,05 maka disimpulkan hipotesis yang menyatakan "Harga berpengaruh signifikan terhadap loyalitas konsumen produk jamur tiram di UD. IRZAN Desa Kalibagor, Kecamatan Situbondo, Kabupaten Situbondo" ditolak. Hasil penelitian ini menunjukkan bahwa secara independen variabel harga tidak berpengaruh secara signifikan terhadap loyalitas konsumen terhadap produk jamur tiram di Desa Kalibagor pada tingkat kepercayaan $95 \%$. 
Hasil uji t pada Variabel harga menunjukkan tidak ada pengaruh yang signifikan terhadap loyalitas konsumen akan produk jamur tiram di Desa Kalibagor, hal itu disebabkan oleh harga yang ditetapkan oleh UD. IRZAN terhadap produk jamur tiram yang mereka hasilkan dikarenakan harga yang ditetapkan oleh UD. IRZAN cukup mahal dikarenakan ketersediaan produk jamur tiram yang masih kekurangan.

Teori permintaan yang dikemukakan oleh Sudarsono (1983), menerangkan bahwa pendapatan dan harga produk mempengaruhi jumlah permintaan, artinya semakin tinggi pendapatan dan harga produk semakin terjangkau maka permintaan akan produk tersebut akan meningkat dan begitupula sebaliknya. Karena pada penelitian ini produk yang menjadi objek adalah jamur tiram, yang mana komoditas tersebut bukan komoditas primer sehingga pengaruh harga terhadap jumlah permintaan tidak signifikan atau pengaruhnya lemah.

\section{Tempat (Place)}

Nilai koefisien tempat (place) adalah sebesar 0,125 yang artinya bahwa setiap peningkatan satu satuan tempat (place), maka akan menaikkan loyalitas konsumen sebesar 0,125 poin terhadap pembelian produk jamur tiram di UD. IRZAN dengan asumsi variabel lainnya tetap. Hal tersebut disebabkan oleh tempat produksi yang bersih sehingga dapat meningkatkan loyalitas konsumen terhadap produk jamur tiram yang mereka tawarkan.

Hasil uji regresi linier berganda pada variabel tempat (place) (X3) terhadap koefisien regresi pada Tabel 3 diperoleh nilai t hitung sebesar 0,676 dengan nilai probabilitas sebesar 0,5. Jika signifikan lebih lebih kecil atau sama dengan $(\leq 0,05)$ maka hipotesis diterima. Dari hasil penelitian diperoleh nilai signifikan pada variabel tempat (place) sebesar 0,5 > 0,05 maka disimpulkan hipotesis yang menyatakan "Tempat (Place) berpengaruh signifikan terhadap loyalitas konsumen terhadap produk jamur tiram di UD. IRZAN Desa Kalibagor, Kecamatan Situbondo, Kabupaten Situbondo" ditolak. Hasil penelitian ini menunjukkan bahwa secara independen variabel tempat (Place) tidak berpengaruh terhadap loyalitas konsumen terhadap produk jamur tiram di UD. IRZAN pada tingkat kepercayaan $95 \%$.

Dari kegiatan penelitian mengungkapkan bahwa UD. IRZAN masih menggunakan peralatan tradisional serta kurangnya pemakaian alat modern membuat pengawasan terhadap tanaman di tempat budidaya tidak optimal sehingga kemungkinan terjadinya kontaminasi samakin tinggi sebab tempat budidaya kurang higienis, selain itu tempat yang susah dijangkau karena berada di perbatasan Situbondo dan Bondowoso sehingga konsumen kesulitan untuk membeli produk jamur tiram di UD. IRZAN. Menurut Basuswastha (1990) mengungkapkan bahwa distribusi semakin sulit lokasi produsen untuk di jangkau oleh konsumen serta semakin sedikit distribusi barang yang menyediakan suatu produk maka akan berpengaruh pada semakin rendahnya loyalitas konsumen.

\section{Promosi (Promotion)}

Nilai koefisien promosi (Promotion) adalah sebesar 0, 04 yang artinya adalah setiap peningkatan satu satuan ketersediaan produk maka akan menaikkan minat beli konsumen sebesar 0,04 kali terhadap pembelian produk jamur tiram di UD. IRZAN dengan asumsi variabel lainnya tetap. Hal tersebut diakibatkan oleh kemudahan yang dirasakan oleh konsumen dalam mendapat produk jamur tiram tersebut.

Hasil uji regresi linier berganda pada variabel promosi (promotion) (X4) terhadap koefisien regresi pada Tabel 3 diperoleh nilai $t$ hitung sebesar 0,227 dengan nilai probabilitas sebesar 0,227 . Jika signifikan lebih lebih kecil atau sama dengan $(\leq 0,05)$ maka hipotesis diterima. Dari hasil penelitian diperoleh nilai signifikan pada variabel promosi (promotion) sebesar 0,227 > 0,05 maka disimpulkan hipotesis yang menyatakan 
"promosi (promotion) berpengaruh terhadap loyalitas konsumen akan produk jamur tiram di UD. IRZAN Desa Kalibagor, Kecamatan Situbondo, Kabupaten Situbondo" ditolak. Hasil penelitian ini menunjukkan bahwa secara independen variabel promosi (promotion) tidak berpengaruh terhadap loyalitas konsumen akan produk jamur tiram di UD. IRZAN pada tingkat kepercayaan 95\%.

Tidak adanya pengaruh signifikan yang disebabkan oleh variabel promosi (promotion) terhadap loyalitas konsumen akan produk jamur tiram di UD. IRZAN dikarenakan produsen jamur tiram di Situbondo masih sedikit sehingga UD. IRZAN merasa promosi tidak diperlukan untuk memperkenalkan produk jamur tiramnya kepada konsumen. Karena permintaan pasar di Situbondo sangat tinggi sehingga konsumen akan tertarik dengan sendirinya tanpa adanya promosi. Menurut Khotler dan amstrong (2008) mengungkapkan bahwa penerapan promosi akan suatu produk yang masih lemahakan berpengaruh penurunan loyalitas konsumen terhadap produk tersebut.

\section{KESIMPULAN \\ Kesimpulan}

Berdasarkan hasil analisis dan pembahasan yang telah dilakukan, maka kesimpulan dari hasil penelitian ini adalah Variabel-variabel dalam strategi pemasaran yang berupa produk (product), harga (place), tempat (place), promosi (promotion) tidak berpengaruh terhadap loyalitas konsumen akan produk jamur tiram UD. IRZAN di Desa Kalibagor, Kecamatan Situbondo, Kabupaten Situbondo hanya secara simultan atau bersama-sama dengan besaran pengaruh yang ditimbulkan adalah 52,3 \% sesdangkan sisanya yakni sebesar $47,7 \%$ dipengaruhi oleh variabel lain diluar penelitian ini.

\section{REFERENSI}

Aaker, D dan Keller, KL. 1990. Consumer Evaluations of Brand Extension. Journal of Marketing, Vol. 54 No.1, January, p. 27-41.

Ferdinand. 2002. Metode Penelitian Manajemen: Pedoman penelitian untuk Skripsi, Tesis, dan Desertasi Ilmu Manajemen, Universitas Diponegoro: Semarang.

Ghozali.2005. Analisis Multivariat dengan Program SPSS. Edisi Ketiga. UNDIP: Semarang.

Gujarati, Damodar N. 2006. Ekonometrika Dasar. Erlangga: Jakarta.

Hakim, Nelly, dkk. 2001.Faktor-Faktor Yang Mempengaruhi Inovasi Produk Sebagai Kinerja Pemasaran. Meutia: Jakarta

Handi, Irwan. 2006. 10 Psinsip Kepuasan Pelanggan. GramediaPustaka Utama: Jakarta.

Harini. 2008. Makroekonomi Pengantar. PT Gramedia Pustaka: Jakarta.

Husein Umar. 2002. Riset Pemasaran dan Perilaku Konsumen. Gramedia Pustaka Utama: Jakarta.

Irawan. 2008. Sepuluh Prinsip Kepuasan Konsumen. Elex Media Komputindo Kelompok Gramedia: Jakarta.

Kotler dan Susanto. 2002. Manajemen Pemasaran di Indonesia. Analis, Perencanaan, Implementasi, dan Pengendalian. Salemba Empat: Jakarta. 
Kotler, Amstrong. 2007. Dasar-dasar Pemasaran. Edisi Bahasa Indonesia. PT. Prehallindo: Jakarta.

Kotler, Philip. 2007.Manajemen Pemasaran Edisi Keduabelas, Edisi Bahasa Indonesia.PT. Indeks: Jakarta.

Kotler, Philip dan Kevin Lane Keller. 2008. Manajemen Pemasaran,Edisi Kedua Belas. PT. Indeks: Jakarta.

Kotler dan Amstrong. 2008. Prinsip - Prinsip Pemasaran. Erlangga: Jakarta.

Kotler dan Keller. 2009. Menajemen Pemasaran, Edisi Ketigabelas. Erlangga: Jakarta.

Kotler dan Amstrong. 2012. Principles of Marketing. PT. Gramedia Pustaka Utama: Jakarta.

Sugiyono. 2000. Statistik Untuk Penelitian. CV. Alfabeta: Bandung.

Sugiyono. 2013.Metode Penelitian Bisnis. CV. Alfabeta: Bandung.

ThomasWZimmerer dan Norman M Scarborough. 2008. Kewirausahaan dan Manajemen Usaha Kecil. Salemba Empat: Jakarta.

Tjiptono, Fandy. 2008. Strategi Pemasaran. Edisi Ketiga. Andi: Yogyakarta.

Tjiptono, Fandy dan Gregorius Chandra. 2012.Pemasaran Strategik. Andi: Yogyakarta. 